\title{
Formulation and Evaluation of Pulav Prepared from Kodo Millet (Paspalum scrobiculatum)
}

\author{
Roopa B. Patil*, K. G. Vijayalakshmi, D. Vijayalakshmi, \\ M. L. Revanna, V. C. Suvarna and V. Palanimuthu \\ Department of Food Science and Nutrition, University of Agricultural Sciences, \\ GKVK, Bangalore, India \\ *Corresponding author
}

\section{A B S T R A C T}

\begin{tabular}{|l|}
\hline Ke y w o r d s \\
Free fatty acid, \\
Kodo millet pulav \\
mix, Microbial, \\
Peroxide value, \\
Sensory scores
\end{tabular}

Kodo millet is a nutritious grain and a good substitute to rice and wheat. Vegetable Pulav is one of the traditional cuisine of the South India. Kodo millet pulav was developed by incorporating kodo millet with broken rice at different variations of 50, 75 and 100 per cent. As per sensory evaluation results 50 per cent incorporated kodo millet pulav was found to be highly acceptable compared to the other variations and selected for developing Ready to cook (RTC) Kodo millet pulav mix using Kodo millet rice, dehydrated vegetables, oil and spices. The developed pulav mix had proten $11.53 \mathrm{~g}, 1.9 \mathrm{~g}$ of minerals, crude fibre $14.27 \mathrm{~g}$, calcium $102 \mathrm{mg}$, iron $5.32 \mathrm{mg}$, magnesium $132.67 \mathrm{mg}$, zinc $2.46 \mathrm{mg}$, copper $0.43 \mathrm{mg}$ and manganese $0.52 \mathrm{mg}$ per $100 \mathrm{~g}$. Shelf life evaluation showed that decreased sensory scores increased moisture content (5.39 to 8.50 per cent), free fatty acid (2.33 to 3.19 per cent), peroxide value (1.20 to $2.15 \mathrm{meq} \mathrm{O} / \mathrm{kg}$ ) and microbial load was within safe limit in the kodo millet incorporated ready to cook pulav mix upto 90 days.

\section{Introduction}

Millets are one of the oldest foods known to humans and possibly the first cereal grain to be used for domestic purposes. Millets are small-seeded grasses that are hardy and grow well in dry zones as rain-fed crops under marginal conditions of soil fertility and moisture (Bommy and Kavitha, 2016). Millets are unique because of their richness in calcium, dietary fibre, polyphenols, carbohydrates (70-80\%) and protein (9-14\%). It is a gluten-free cereal and also rich in phytochemicals which help to lower cholesterol level and reduced cancer risk due to its phytate content (Shadang and Jaganathan, 2014). Global millet production was estimated as 27.83 million tons (FAO, 2014). An estimation says Kodo millet is grown in area of about 907,800 ha with annual production of about 310,710 tonnes (Yadav et al., 2013). Once a poor man's staple, now adorns the plates of affluent and health conscious people. One of such ancient millet grains is kodo millet, a native of tropical Africa, believed to be domesticated in 
India about 3000 years back. Kodo is also described as nutritious millet and has received far less research and development attention than other crops with regard to crop improvement and utilization. Nutritionally Kodo millet a fair source of protein, which is highly digestible and is an excellent source of dietary fibre with good amounts of soluble and insoluble fractions. The carbohydrate content is low and slowly digestible (Deshpande et al., 2015). A fast paced urban lifestyle, increasing dominance of nuclear family structure, rising disposable income, convenience of use have made RTE foods popular. Provision of such RTE foods based on nutritious grains such as millets would be more meaningful in the modern times in the management of life style disorders (Takhellamban et al., 2015). Considering the above mentioned nutritional and health benefits of millets, a research study was conducted to formulate and standardize the pulav from dehulled kodo millet with broken rice at different incorporation levels and also to standardize and to assess the shelf life of formulated ready to cook pulav mix.

\section{Materials and Methods}

\section{Procurement of raw materials}

Kodo millet was procured from the local farmers of Gopalanahalli of Chikkanayakanahalli taluk of Tumkur district of Karnataka, India. The grains were cleaned and dehulled in Millet Processing unit of Farmers Grower's Association, Gopalanahalli of Tumkur district. The grains were cleaned to remove dust, other foreign materials, used to standardize the pulav and for proximate analysis.

\section{Formulation of Kodo millet pulav}

Kodo millet Pulav was standardized by incorporating kodo millet rice with broken rice at $50 \%(\mathrm{KPT} 1), 75 \%(\mathrm{KPT} 2)$, and $100 \%$ (KPT3) and control pulav was prepared from $100 \%$ broken rice (KPC). The ingredients used for the preparation of the pulav are given in Table 1.

The flow chart for preparation of pulav is given in Figure 1.

\section{Sensory evaluation}

Sensory evaluation of the control and all the variations was done with the help of nine point hedonic scale by a panel of twenty one semitrained judges.

\section{Ready to cook (RTC) Kodo millet pulav mix}

The best accepted product variation was selected for the development of pulav mix KPT1 (50\%). The soaked (one hour) and dried Kodo millet rice $(50 \mathrm{~g})$ and broken rice $(50 \mathrm{~g})$, total of $100 \mathrm{~g}$ mixed rice were roasted in stainless steel on flame with constant stirring till the roast attained $150 \pm 3^{\circ} \mathrm{C}$ and started to give characteristics aroma and colour of a cooked product. Oil $(15 \mathrm{ml})$ was heated $\left(180 \pm 5^{\circ} \mathrm{C}\right)$ in a pan, spices and vegetables namely cinnamon (1 inch pieces 2 nos), cardomum (2 nos), clove (2 nos), pepper (4 nos), dehydrated ginger garlic powder $(2.5 \mathrm{~g})$, peas $(8 \mathrm{~g})$, onion $(5 \mathrm{~g})$, chilli $(1 \mathrm{~g})$, potato $(8$ $\mathrm{g})$, carrot (4 g), beans (4 g), mint leaves (1.25 $\mathrm{g})$, coriander leaves $(2 \mathrm{~g})$ were shallow fried. Preprocessed and roasted kodo millet rice and broken rice were added in the pan and mixed properly with oil. Salt $(2.5 \mathrm{~g})$ was added to the contents of the pan. The samples were cooled and packed in Aluminium pouches and stored at ambient condition $\left(20-35^{\circ} \mathrm{C}\right)$.

\section{Pulav from RTC pulav mix}

To the one cup of Kodo millet pulav mix three cups of water was boiled in pressure 
cooker. kodo millet pulav mix and salt were added to boiling water and it was cooked for three whistles.

\section{Nutrient composition of pulav mixes}

All analysis were done by following the AOAC (1980) official protocols. Moisture was determined from sample weight loss after drying at $110^{\circ} \mathrm{C}$ for $4 \mathrm{~h}$. Protein $(\mathrm{g})$ content was determined by Kjeldahl method. The Soxhlet method was used for total fat (g) determination. Crude fiber was estimated by treatment of sample first with acid and subsequently with alkali. The loss in weight was the crude fibre content. Carbohydrate and energy by difference method (Livesey, 1995). Ash by muffle furnace, micronutrients (mg) iron, zinc and copper by using Atomic Absorption Spectrophotometer and calcium and magnesium by titration method. All samples were analyzed in triplicates.

\section{Storage quality evaluation}

The Control and kodo millet pulav mixes were packed in Aluminium pouches, heat sealed and stored in cardboard boxes at ambient temperature for a period of 90 days. The storage quality of Control pulav mix and kodo millet pulav mixes were evaluated for moisture content, free fatty acid (FFA), peroxide value (PV), sensory quality and microbial population at the interval of 30 days for a period of 90 days. Sensory evaluation was carried out for the stored product in the form of cooked pulav.

\section{Statistical analysis}

All the experiments were performed in triplicate and completely randomized design was carried out for the experimental values in order to know the significant difference (at $5 \%$ significant level) using statistical software (OP stat).

\section{Results and Discussion}

\section{Sensory evaluation of formulated products}

The mean scores of pulav prepared from kodo millet incorporated with broken rice is depicted in Table 2. Control pulav had the highest scores for all the sensory parameters. Among the variations highest scores for appearance, colour, flavour, texture, taste and overall acceptability (7.98, 7.98, 8.07, 7.89, 8.08 and 8.11 respectively) were recorded for 50 per cent kodo millet incorporated pulav KPT1 and least scores was for $100 \%$ Kodo millet incorporated variation i.e. KPT3 However, the difference in scores for all the sensory parameters among the variations was found to be statistically significant (Figure 2).

Mohana Vidhya and Roobhadevi (2014) formulated and standardized ready to cook mixes by incorporating kodo millet at $10 \%$, $20 \%$ and $30 \%$ respectively and assessed the shelf life and reported that ready to cook mixes with kodo millet were highly acceptable.

Table 3 shows nutrient composition per 100 gpulav mix. It was found that the protein content of kodo millet based pulav was higher $(10.00 \pm 0.1)$ than the control pulav $(11.53 \pm$ 0.15). Control pulav had relatively higher carbohydrate content $(65.97 \mathrm{~g} \pm 0.32)$. Carbohydrate in kodo millet pulav was observed to be $60.39 \mathrm{~g} \pm 0.64$. Fat content of kodo millet and control pulav were $5.20 \pm$ 0.17 and $6.06 \pm 0.20$. Calcium content was also higher in millet based pulav (102.00 \pm 2.00) than control pulav $(86.00 \pm 1.73)$. Iron, magnesium, zinc, copper and manganese content of kodo millet pulav were $5.32 \pm 0.33$, $132.67 \pm 1.15,2.46 \pm 0.37,0.43 \pm 0.02 \&$ $0.52 \pm 0.04$ and control pulav were $3.11 \pm$ $0.18,91.00 \pm 1.00,1.77 \pm 0.11,0.28 \pm 0.06 \&$ $0.71 \pm 0.09$ respectively. Study conducted by Verma et al., 2015 also concluded that biryani 
prepared from barnyard millet and foxtail millet had higher contents of protein, fat, fibre, calcium and iron as compared to biryani prepared from rice (control).

Table 4 depicts the sensory scores of pulav during storage. As expected the scores for sensory attributes decreased as the number of days of storage increased. The decrease in appearance was significant from initial to $30^{\text {th }}$ (8.40) and $60^{\text {th }}(7.36)$ day. But the decrease from $60^{\text {th }}$ to $90^{\text {th }}$ was not significant $(7.36$ and 7.32 respectively).Where as in kodo millet pulav appearance did not changed upto $30^{\text {th }}$ day (8.39 and 8.17), but decreased significantly from $30^{\text {th }}$ day to $60^{\text {th }}$ day and $90^{\text {th }}$ day (7.29 and 7.07 respectively), but change is not significant on $60^{\text {th }}$ and $90^{\text {th }}$ day. Texture (8.43 and 8.16), colour (8.53 and 8.22 ) and flavor (8.48 and 7.99) decreased but it was not significant in control pulav from initial to $30^{\text {th }}$ day but decreased significantly from $30^{\text {th }}$ day to $60^{\text {th }}$ day and $90^{\text {th }}$ day. Taste in control pulav decreased significantly from initial (8.31) to $90^{\text {th }}$ day (7.64) (Figure 3 and Figure 4).

Table.1 Ingredients used in the preparation of control and Kodo millet Pulavs

\begin{tabular}{|l|c|c|c|c|}
\hline Ingredients & Control & \multicolumn{3}{|c|}{ Variations } \\
\hline Broken rice & KPC & KPT1 (50\%) & KPT2(75\%) & KPT3(100\%) \\
\hline Kodo millet rice & $40 \mathrm{~g}$ & $20 \mathrm{~g}$ & $10 \mathrm{~g}$ & - \\
\hline Oil & - & $20 \mathrm{~g}$ & $30 \mathrm{~g}$ & $40 \mathrm{~g}$ \\
\hline Spices & $10 \mathrm{ml}$ & $10 \mathrm{ml}$ & $10 \mathrm{ml}$ & $10 \mathrm{ml}$ \\
\hline Ginger garlic paste & $1 \mathrm{~g}$ & $5 \mathrm{~g}$ & $5 \mathrm{~g}$ & $5 \mathrm{~g}$ \\
\hline Onion & $20 \mathrm{~g}$ & $1 \mathrm{tsp}$ & $1 \mathrm{tsp}$ & $1 \mathrm{tsp}$ \\
\hline Green Chillies & $5 \mathrm{~g}$ & $5 \mathrm{~g}$ & $20 \mathrm{~g}$ & $20 \mathrm{~g}$ \\
\hline Potato & $20 \mathrm{~g}$ & $20 \mathrm{~g}$ & $20 \mathrm{~g}$ & $20 \mathrm{~g}$ \\
\hline Carrot & $20 \mathrm{~g}$ & $20 \mathrm{~g}$ & $20 \mathrm{~g}$ & $20 \mathrm{~g}$ \\
\hline Peas & $20 \mathrm{~g}$ & $20 \mathrm{~g}$ & $20 \mathrm{~g}$ & $20 \mathrm{~g}$ \\
\hline mint leaves & $1 \mathrm{~g}$ & $1 \mathrm{~g}$ & $1 \mathrm{~g}$ & $1 \mathrm{~g}$ \\
\hline Salt & $1 \mathrm{~g}$ & $1 \mathrm{~g}$ & $1 \mathrm{~g}$ & $1 \mathrm{~g}$ \\
\hline
\end{tabular}

Table.2 Mean sensory scores of Kodo millet Pulav

\begin{tabular}{|l|c|c|c|c|c|c|}
\hline \multirow{2}{*}{ Products } & \multicolumn{7}{|c|}{ Sensory attributes } \\
\cline { 2 - 7 } & Appearance & Colour & Flavour & Texture & Taste & Overall acceptability \\
\hline KPC (Control) & 8.33 & 8.29 & 8.29 & 8.19 & 8.33 & 8.29 \\
\hline KPT1 (50\%) & 7.98 & 7.98 & 8.07 & 7.89 & 8.08 & 8.11 \\
\hline KPT2 (75\%) & 7.68 & 7.60 & 7.81 & 7.82 & 8.04 & 7.84 \\
\hline KPT3 (100\%) & 7.19 & 7.10 & 7.43 & 7.29 & 7.49 & 7.35 \\
\hline F Value & $*$ & $*$ & $*$ & $*$ & $*$ & $*$ \\
\hline SE(m) & 0.21 & 0.21 & 0.17 & 0.17 & 0.48 & 0.17 \\
\hline C.D at 5\% & 0.59 & 0.58 & 0.48 & 0.47 & 0.16 & 0.48 \\
\hline
\end{tabular}


Table.3 Nutrient composition of Kodo millet Pulav mix (KPT1)

\begin{tabular}{|l|c|c|}
\hline Nutrients & \multicolumn{2}{|c|}{ Pulav mix per 100 g } \\
\hline Moisture (g) & Control Pulav mix (KPC) & KodoPulav mix (KPT 50\%) \\
\hline Fat (g) & $6.49 \pm 0.15$ & $5.83 \pm 0.59$ \\
\hline Protein (g) & $5.20 \pm 0.17$ & $6.06 \pm 0.20$ \\
\hline Ash (g) & $10.00 \pm 0.1$ & $11.53 \pm 0.15$ \\
\hline Crude fibre (g) & $1.62 \pm 0.10$ & $1.9 \pm 0.03$ \\
\hline Carbohydrate (g) & $10.53 \pm 0.28$ & $14.27 \pm 0.74$ \\
\hline Energy (Kcal) & $65.97 \pm 0.32$ & $60.39 \pm 0.64$ \\
\hline Calcium (mg) & $350.68 \pm 2.32$ & $341.68 \pm 1.85$ \\
\hline Iron (mg) & $86.00 \pm 1.73$ & $102.00 \pm 2.00$ \\
\hline Magnesium (mg) & $3.11 \pm 0.18$ & $5.32 \pm 0.33$ \\
\hline Zinc (mg) & $91.00 \pm 1.00$ & $132.67 \pm 1.15$ \\
\hline Copper (mg) & $1.77 \pm 0.11$ & $2.46 \pm 0.37$ \\
\hline Manganese (mg) & $0.28 \pm 0.06$ & $0.43 \pm 0.02$ \\
\hline
\end{tabular}

Values are mean of three triplicates \pm SD

Table.4 Mean sensory scores of Pulavs during storage study

\begin{tabular}{|c|c|c|c|c|c|c|c|}
\hline \multirow[t]{2}{*}{ Products } & \multirow[t]{2}{*}{ Duration } & \multicolumn{6}{|c|}{ Sensory attributes } \\
\hline & & Appearance & Texture & Colour & Flavour & Taste & Overall acceptability \\
\hline \multirow{7}{*}{ KPC } & Initial & $8.40^{\mathrm{a}}$ & $8.43^{\mathrm{a}}$ & $8.53^{\mathrm{a}}$ & $8.48^{\mathrm{a}}$ & $8.31^{\mathrm{a}}$ & $8.29^{\mathrm{a}}$ \\
\hline & $30^{\text {th }}$ day & $8.00^{\mathrm{b}}$ & $8.16^{\mathrm{a}}$ & $8.22^{\mathrm{a}}$ & $7.99^{\mathrm{a}}$ & $8.12^{\mathrm{bc}}$ & $8.19^{\mathrm{a}}$ \\
\hline & $60^{\text {th }}$ day & $7.36^{\mathrm{cd}}$ & $7.53^{\mathrm{b}}$ & $7.58^{\mathrm{bc}}$ & $7.57^{\mathrm{bc}}$ & $7.86^{\mathrm{cd}}$ & $7.43^{\mathrm{bc}}$ \\
\hline & $90^{\text {th }}$ day & $7.32^{\mathrm{d}}$ & $7.17^{\mathrm{c}}$ & $7.43^{c}$ & $7.02^{c}$ & $7.64^{d}$ & $7.27^{c}$ \\
\hline & F value & $*$ & $*$ & $*$ & $*$ & $*$ & $*$ \\
\hline & $\mathrm{SE}(\mathrm{m})$ & 0.13 & 0.10 & 0.12 & 0.15 & 0.12 & 0.14 \\
\hline & CD & 0.38 & 0.28 & 0.34 & 0.42 & 0.36 & 0.39 \\
\hline \multirow{7}{*}{ KPT } & Initial & $8.39^{\mathrm{a}}$ & $8.19^{\mathrm{a}}$ & $8.51^{\mathrm{a}}$ & $8.41^{\mathrm{a}}$ & $8.38^{\mathrm{a}}$ & $8.32^{\mathrm{a}}$ \\
\hline & $30^{\text {th }}$ day & $8.17^{\mathrm{a}}$ & $7.96^{\mathrm{a}}$ & $8.12^{\mathrm{a}}$ & $8.00^{\mathrm{a}}$ & $7.87^{\mathrm{bcd}}$ & $8.25^{\mathrm{a}}$ \\
\hline & $60^{\text {th }}$ day & $7.29^{\mathrm{bc}}$ & $7.23^{b c}$ & $7.52^{\mathrm{bc}}$ & $7.45^{\mathrm{bc}}$ & $7.76^{\mathrm{cd}}$ & $7.81^{\mathrm{ab}}$ \\
\hline & $90^{\text {th }}$ day & $7.07^{\mathrm{c}}$ & $7.01^{\mathrm{c}}$ & $7.21^{\mathrm{c}}$ & $7.07^{\mathrm{c}}$ & $7.44^{\mathrm{d}}$ & $7.55^{\mathrm{b}}$ \\
\hline & $F$ value & $*$ & $*$ & $*$ & $*$ & $*$ & $*$ \\
\hline & $\mathrm{SE}(\mathrm{m})$ & 0.11 & 0.15 & 0.158 & 0.19 & 0.16 & 0.18 \\
\hline & $\mathrm{CD}$ & 0.29 & 0.41 & 0.44 & 0.53 & 0.45 & 0.51 \\
\hline
\end{tabular}

*significant

$* P \leq 0.05$, Values in the same column bearing different superscripts are significantly different KPC - Pulav control, KPT-Kodo millet pulav treatment (50\%) 
Table.5 Moisture, Free fatty acids and peroxide value of control and kodo millet pulav on storage

\begin{tabular}{|c|c|c|c|c|}
\hline Products & Duration & Moisture (\%)) & FFA $(\%)$ & PV(meq 2/kg \\
\hline \multirow[t]{7}{*}{ KPC } & Initial & $6.84^{\mathrm{a}}$ & $1.33^{\mathrm{a}}$ & $0.42^{\mathrm{a}}$ \\
\hline & $30^{\text {th }}$ day & $7.26^{\mathrm{a}}$ & $1.66^{b c}$ & $1.01^{\mathrm{a}}$ \\
\hline & $60^{\text {th }}$ day & $8.94^{b c}$ & $1.84^{c}$ & $1.24^{b}$ \\
\hline & $90^{\text {th }}$ day & $9.46^{\mathrm{c}}$ & $2.32^{d}$ & $1.47^{\mathrm{c}}$ \\
\hline & F value & $*$ & $*$ & $*$ \\
\hline & $\mathrm{SE}(\mathrm{m})$ & 0.16 & 0.08 & 0.05 \\
\hline & C.D. & 0.54 & 0.28 & 0.17 \\
\hline \multirow[t]{7}{*}{ KPT } & Initial & $5.39^{\mathrm{a}}$ & $2.33^{\mathrm{a}}$ & $1.20^{\mathrm{a}}$ \\
\hline & $30^{\text {th }}$ day & $6.06^{\mathrm{a}}$ & $2.66^{b}$ & $1.27^{\mathrm{a}}$ \\
\hline & $60^{\text {th }}$ day & $7.64^{b c}$ & $3.05^{\mathrm{cd}}$ & $1.38^{\mathrm{a}}$ \\
\hline & $90^{\text {th }}$ day & $8.50^{c}$ & $3.19^{\mathrm{d}}$ & $2.15^{b}$ \\
\hline & $\mathrm{F}$ value & $*$ & $*$ & $*$ \\
\hline & $\mathrm{SE}(\mathrm{m})$ & 0.34 & 0.08 & 0.09 \\
\hline & C.D. & 1.10 & 0.28 & 0.31 \\
\hline
\end{tabular}

*significant

$* P \leq 0.05$, Values in the same column bearing different superscripts are significantly different KPC - Pulav control, KPT-Kodo millet pulav treatment (50\%)

Table.6 Microbial population of control and kodo millet pulav on storage

\begin{tabular}{|c|c|c|c|c|}
\hline \multirow[t]{2}{*}{ Products } & \multirow{2}{*}{$\begin{array}{l}\text { Duration } \\
\text { (days) }\end{array}$} & \multicolumn{3}{|c|}{ Population of microorganisms } \\
\hline & & $\begin{array}{c}\text { Bacteria } \\
\left(\mathbf{x 1 0}^{4} \mathrm{cfu} / \mathrm{g}\right)\end{array}$ & $\begin{array}{c}\text { Funngi } \\
\left(\times 10^{2} \text { cfu/g) }\right.\end{array}$ & $\begin{array}{c}\text { Coliforms } \\
\left(\times 10^{2} \text { cfu/g) }\right.\end{array}$ \\
\hline \multirow{7}{*}{ KPC } & Initial & $0.67^{\mathrm{a}}(1.081)$ & $0.00(0.707)$ & $0.00(0.707)$ \\
\hline & $30^{\text {th }}$ day & $1.77^{b}(1.506)$ & $0.00(0.707)$ & $0.00(0.707)$ \\
\hline & $60^{\text {th }}$ day & $2.13^{\mathrm{c}}(1.621)$ & $0.00(0.707)$ & $0.00(0.707)$ \\
\hline & $90^{\text {th }}$ day & $3.67^{\mathrm{d}}(2.042)$ & $0.00(0.707)$ & $0.00(0.707)$ \\
\hline & F value & $*$ & NS & NS \\
\hline & $\mathrm{SE}(\mathrm{m})$ & 0.04 & 0.00 & 0.00 \\
\hline & $\mathrm{CD}$ at $5 \%$ & 0.15 & - & - \\
\hline \multirow[t]{7}{*}{ KPT } & Initial & $0.33^{\mathrm{a}}(0.911)$ & $0.00(0.707)$ & $0.00(0.707)$ \\
\hline & $30^{\text {th }}$ day & $1.77^{b}(1.506)$ & $0.00(0.707)$ & $0.00(0.707)$ \\
\hline & $60^{\text {th }}$ day & $3.20^{c}(1.923)$ & $0.00(0.707)$ & $0.00(0.707)$ \\
\hline & $90^{\text {th }}$ day & $3.60^{\mathrm{d}}(2.024)$ & $0.00(0.707)$ & $0.00(0.707)$ \\
\hline & F value & $*$ & NS & NS \\
\hline & $\mathrm{SE}(\mathrm{m})$ & .04 & 0.00 & 0.00 \\
\hline & $\mathrm{CD}$ at $5 \%$ & 0.14 & - & - \\
\hline
\end{tabular}

*-Significant, NS- Non significant

$* P \leq 0.05$, Values in the same column bearing different superscripts are significantly different KPC - Pulav control, KPT-Kodo millet pulav treatment (50\%)

Values in parenthesis indicate $(\sqrt{ } x+0.5)$ 
Fig.1 Flow chart for the preparation of Pulav

Grains were washed and soaked for one hour Oil was heated in a pan and spices and onion were added and fried till soft $\downarrow$

Green chillies and ginger garlic paste were added and fried for 3-4 minutes $\downarrow$

Chopped vegetables, mint leaves and salt were added and fried for a minute $\downarrow$

Required quantity of water was added $\downarrow$

Kodo millet rice was added to boiling water and mixed well $\downarrow$

It was cooked in pressure cooker till 3 whistles

Fig.2 Mean sensory scores of Kodo millet pulav

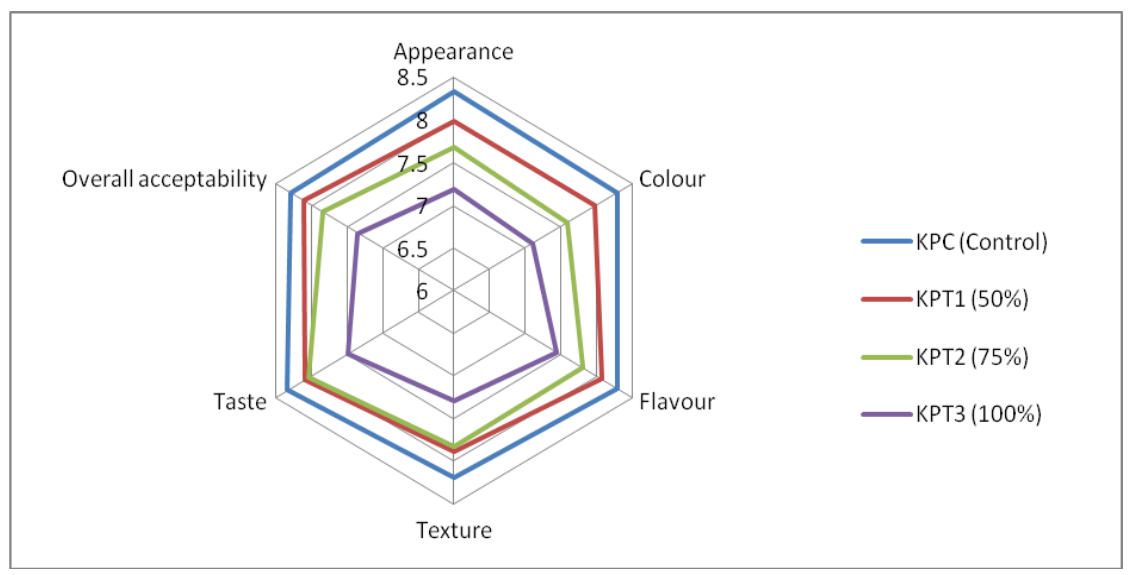

Fig.3 Mean sensory scores of Control pulav

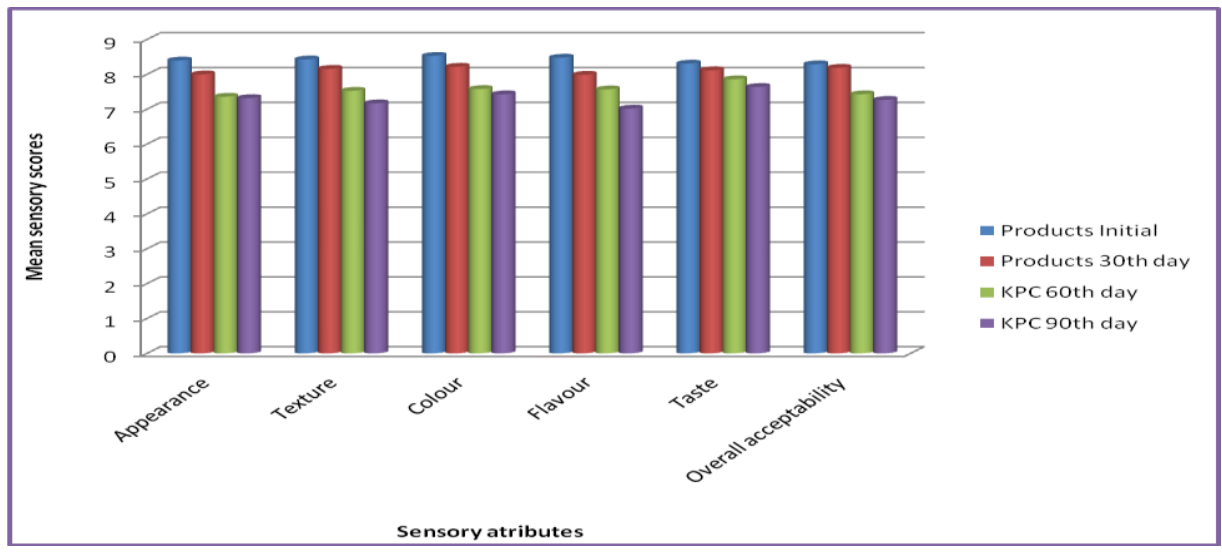


Fig.4 Mean sensory scores of kodo millet pulav

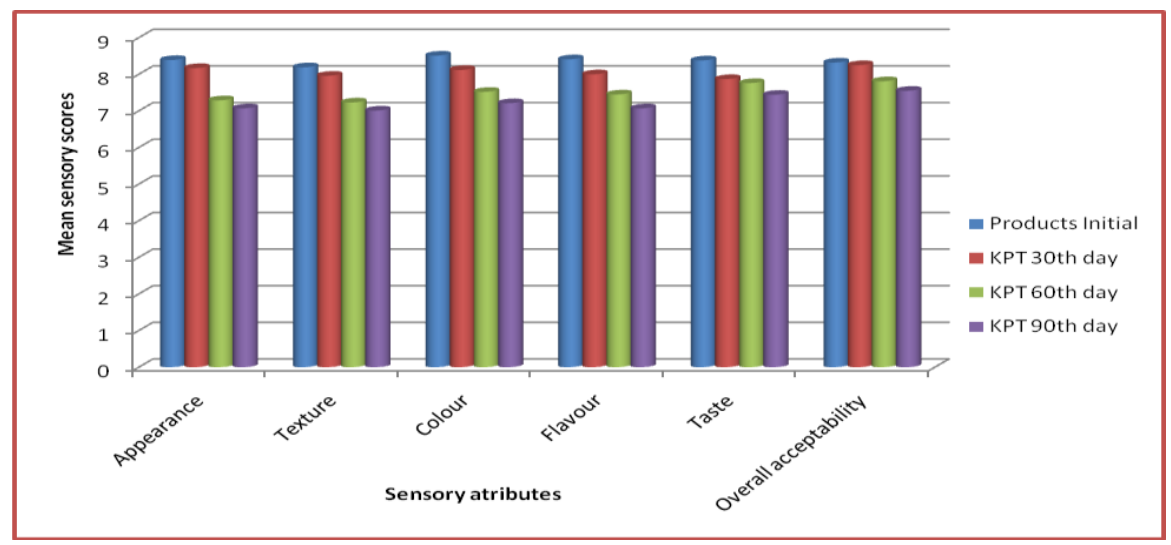

However, over all acceptability did not change from initial to $30^{\text {th }}$ day (8.29 and $8.19)$, but decreased significantly from $30^{\text {th }}$ day to $90^{\text {th }}$ day (7.43 and 7.27). In kodo millet pulav appearance (8.39 and 8.17), texture (8.19 and 7.96), colour (8.51 and 8.12) and flavor (8.41 and 8.00)did not change from initial to $30^{\text {th }}$ day, but decreased significantly from $60^{\text {th }}(7.29,7.23,7.52$ and 7.45$)$ day to $90^{\text {th }}$ day $(7.07,7.01,7.21$ and 7.07). Taste of kodo millet pulav decreased significantly from initial to $90^{\text {th }}$ day ( 8.38 to 7.44 ). The over all acceptability did not change upto to $60^{\text {th }}$ day $(8.32,8.25$ and 7.81 respectively), but decreased significantly on $90^{\text {th }}$ day (7.55). Kavita et al., 2015 also reported that the taste and aroma scores for avalakki were 7.20 each on initial storage period which did not change till 5th month of storage (6.60 and 6.40, respectively). However, on $6^{\text {th }}$ month the scores decreased gradually (5.70 and 5.60, respectively), but the flakes were acceptable till the end of 6th month.

Effect of storage on moisture, Free fatty acid content and peroxide value for control and kodo millet pulav is given in Table 5.Moisture content did not change from initial $(6.84 \%$ and $7.26 \%)$ to $30^{\text {th }}$ day $(5.39 \%$ and $6.06 \%)$, but increased significantly $(\mathrm{p}<0.05)$ on $60^{\text {th }}(8.94 \%$ and $7.64 \%)$ and $90^{\text {th }}$ day $(9.46 \%$ and $8.50 \%)$ in both the products.
Storage of pulav for 90 days at ambient temperature significantly $(\mathrm{p}<0.05)$ increased the FFA content from 1.33 (Initial) to 2.32 per cent in control pulav and 2.33 (Initial storage) to 3.19 per cent in kodo millet pulav (KPT) on $90^{\text {th }}$ day of storage. Free fatty acid content between storage durationof $30^{\text {th }}$ day and $60^{\text {th }}$ day in control pulav and between $60^{\text {th }}$ day and $90^{\text {th }}$ day in kodo millet pulav was not significant. Peroxide value (PV) of extracted lipids increased significantly $(\mathrm{p}<0.05)$ from 0.42 (Initial day) to $1.47\left(90^{\text {th }}\right.$ day) meq $\mathrm{O}_{2}$ per $\mathrm{kg}$ in control pulav and 1.20 (Initial) to 2.15( $\left(90^{\text {th }}\right.$ day) meq $\mathrm{O}_{2}$ per $\mathrm{kg}$ in kodo millet pulav. PV between storage duration between initial day and $30^{\text {th }}$ day in control pulav and storage duration between initial day, $30^{\text {th }}$ day and $60^{\text {th }}$ day in kodo millet pulav was not significant. Similar study was by Kavita et al., (2015) who reported that little millet flakes showed a small increase in moisture uptake during storage from $10.11 \%$ (0 month) to $11.82 \%$ (6th month). Free fatty acid content increased from $9.20 \%(0 \mathrm{~m})$ to $18.02 \%\left(6^{\text {th }}\right.$ month).

Microbial population of control and kodo millet pulav on storage at different intervals for bacteria, fungi and coliforms by standard plate count is presented in Table 6. Bacterial count increased significantly from initial day of storage to $90^{\text {th }}$ day of storage in control 
pulav $\left(0.67,1.77,2.13\right.$ and $3.67 \times 10^{4} \mathrm{cfu} / \mathrm{g}$ respectively) and also in kodo millet pulav $\left(0.33,1.77,3.2\right.$ and $\left.3.60 \times 10^{4} \mathrm{cfu} / \mathrm{g}\right)$. There were no mould colonies and coliform colonies reported in control and kodo millet pulav from initial day to $90^{\text {th }}$ day of storage. Similar finding were noted by Mohana Vidhya and Roobhadevi, 2014 that at the initial stage, the colony formation (Streptococci $\mathrm{sp}$ ) was very low in all the ready to cook mixes and there was a slight increase in the bacterial count on the $45^{\text {th }}$ day of storage, however the levels of the bacterial count was within the recommended standard.

In conclusion the RTC Kodo millet pulav thus not only convenient but also found to be rich in fibre and micro nutrients like calcium and iron. Shelf life study revealed that it is safe for consumption till 90 days of storage. Hence, from the present study it can be concluded that acceptable pulav can be developed with kodo millet without affecting the sensory qualities and health benefits of Kodo millet can be exploited.

The best accepted product variation was selected for the development of pulav mix KPT1 $(50 \%)$. The soaked (one hour) and dried Kodo millet rice $(50 \mathrm{~g})$ and rice grits $(50 \mathrm{~g})$, total of $100 \mathrm{~g}$ mixed rice were roasted in stainless steel on flame with constant stirring till the roast attained $150 \pm 3{ }^{\circ} \mathrm{C}$ and started to give characteristics aroma and colour of a cooked product. Oil $(15 \mathrm{ml})$ was heated $\left(180 \pm 5^{\circ} \mathrm{C}\right)$ in a pan spices and vegetables namely cinnamon (1 inch pieces 2 nos), cardomum (2 nos), clove ( 2 nos), pepper (4 nos), dehydrated ginger garlic powder (2.5 $\mathrm{g}$ ), peas $(8 \mathrm{~g})$, onion $(5 \mathrm{~g})$, chilli $(1 \mathrm{~g})$, potato $(8 \mathrm{~g})$, carrot $(4 \mathrm{~g})$, beans $(4 \mathrm{~g})$, mint leaves $(1.25 \mathrm{~g})$, coriander leaves $(2 \mathrm{~g})$ were shallow fried. Preprocessed and roasted kodo millet rice and rice grits were added in the pan and mixed properly with oil. Salt $(2.5 \mathrm{~g})$ was added to the contents of the pan. The samples were cooled and packed in Aluminium pouches.

\section{References}

AOAC, 2000, Official Methods of Analysis, 17th Ed., Washington DC.

Bommy, D. and Kavitha, M. S., 2016, Promotion of Millets Cultivation through Consumption. International Journal of Current Research and Academic Review., 3: 74-80.

Deshpande, S. S., Mohapatra, D., Tripathi, M. K. and Sadvatha R H., 2015, Kodo Millet-Nutritional Value and Utilization in Indian Foods. Journal of Grain Processing and Storage., 2 (2): 16-23.

FAOSTAT: http://faostat3.fao.org/home/E. Food and Agriculture Organization, Rome.

Livesey, G., 1995, Metabolizable energy of macro nutrients. Am. J. Clin. Nutr.,62: $1135-1142$.

Mohana Vidhya, A. and Roobhadevi, M. M., 2014, Formulation and Shelflife Evaluation of Kodo Millet Incorporated Ready to Cook Mixes. Food Sci: Indian Journal of Research in Food Science and Nutrition., 1(1): 27-31.

Patil, K. B., Chimmad, B. V and Itagi, S., 2015, Glycemic index and quality evaluation of little millet (Panicum miliare) flakes with enhanced shelf life. J Food Sci Technol., 52(9):6078-6082.

Shadang, C and Jaganathan, D., 2014, Development standardization of formulated baked product using millet. International Journal of Research in Applied, Natural and Social Sciences., 2(9): 75-78.

Takhellamban, R.D., Chimmad, B.V. 2015. Ready - to - cook millet flakes based on minor millets for modern consumer. J. Food Technol., 4(1): 64-69.

Verma, S., Srivastava, S and Tiwari, N., 2015, Comparative study on nutritional 
and sensory quality of barnyard and foxtail millet food products with traditional rice products. $J$ Food $S c i$ Technol., 52(8): 5147-5155. Yadav, N., Chaudhary, K., Singh, A. and
Gupta, A., 2013, Evaluation of hypoglycemic properties of kodo millet based food products in healthy subjects. Www. Iosrphr., 3: 14-20.

\section{How to cite this article:}

Roopa B. Patil, K. G. Vijayalakshmi, D. Vijayalakshmi, M. L. Revanna, V. C. Suvarna and Palanimuthu, V. 2020. Formulation and Evaluation of Pulav Prepared from Kodo Millet (Paspalum scrobiculatum). Int.J.Curr.Microbiol.App.Sci. 9(09): 2817-2826.

doi: https://doi.org/10.20546/ijcmas.2020.909.348 